\title{
男性におけるrectoceleの検討
}

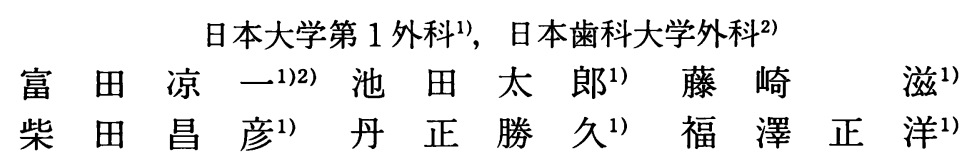

\section{Clinical Assessments of Male Patients with Rectocele}

\author{
Ryouichi TOMITA $^{12)}$, Tarou IKEDA ${ }^{1)}$, Shigeru FUJISAKI ${ }^{12}$, \\ Masahiko SHIBATA ${ }^{1)}$, Katsuhisa TANJOH ${ }^{1)}$ and Masahiro FUKUZAWA ${ }^{1)}$ \\ ${ }^{1)}$ First Department of Surgery, Nihon University School of Medicine \\ ${ }^{2)}$ Department of Surgery, The Nippon Dental University School of Dentistry at Tokyo
}

排便障害を主訴として来院した男性71例にdefecographyを行った。その結果, rectoceleを伴う症例は 8 例 (A 群 : 15 73歳, 平均48.6歳), 伴わない症例は63例 (B群：28 74歳, 平均52.6歳)であった。A群はB群より明ら かに, 残便感, 手術既往 (前立腺摘出術, 低位前方切除術, 痔核切除術), 直腸壁と骨盤底筋群の異常, などを多 く認めた。よって, 男性のrectoceleの成因には, 前立腺切除, 手術操作による骨盤底筋群や直腸周囲支持組織の 脆弱化などの関与が考之られた。しかし, rectoceleは $2 \mathrm{~cm}$ 以下と小さく, その他の直腸壁異常と骨盤底筋群異常 とを認めたことから，残便感の原因とは考えにくかった。

索引用語：直腸瘤（rectocele), 男性 (male), 排便注腸造影 (defecography), 臨床的所見 (clinical findings)

\section{はじめに}

最近，直腸肛門における形態学的および機能的 異常を認める疾患が, defecography法（排便注腸 造影検査）を検査手段に応用するようになり，診

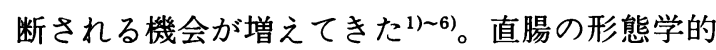
異常のなかでよく経験される rectoceleは女性に 多く認められ, 排便障害症状（残便感や排便困難 など）を訴えることから，その原因疾患に挙げら れるようになってきだ(1)。一方, 男性のrectocele は稀であるため, これまで臨床家にあまり注目さ れず，对象を男性のみに限定した研究報告 ${ }^{6) 7}$ は極 めて少ない。そこで，われわれは排便障害を主訴 とした男性にdefecographyを施行し, rectoceleと 診断された症例について臨床的特徵を検討した。

\section{対象と方法}

\section{1. 研究対象}

過去 4 年間に, 日本大学板橋病院第 1 外科外来 で経験した，排便時に何らかの愁訴（残便感, 排 便困難, 便秘など）を有し来院した症例は71例で ある。これらを, rectoceleを伴う 8 例（A群： 15 73歳, 平均48.6歳) と伴わない63例（B群： 28 74歳, 平均52.6歳) の 2 群に分類し, 再群間 の臨床的特徵を検討した。

なお, infomed consentとして, 对象症例とその 家族に対して，排便時の愁訴には直腸肛門の形態 学的および機能的異常を呈する疾患が存在し，そ の診断にはdefecographyが有用である主旨を説 明し，本検查の重要性を理解してもらうようにし た。そして，本検查に同意してくれた症例のみを 


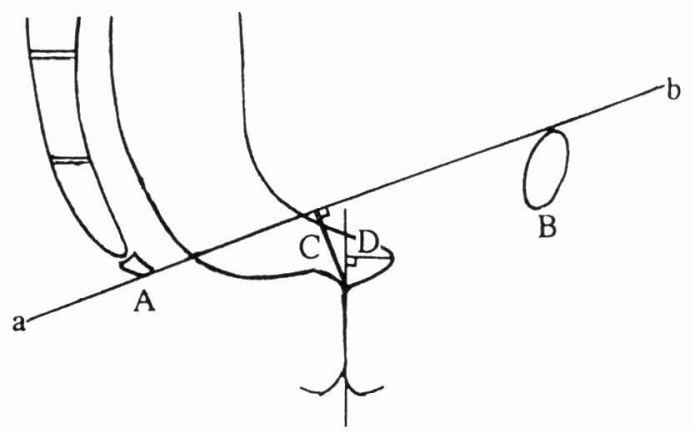

Fig. 1 Anatomic parameters for defecogram

A : Coccyx, B:Pubis, C:Perineal descent, D: Length (size) of rectocele

$a b$ : The pubococcygeal line

対象とした。

\section{2 . 研究方法}

注腸用バリウム $120 \mathrm{ml}$ に小麦粉 $150 \mathrm{~g}$ をよく攪抖 し人工便を作製した。そして，被検者を左側臥位 にした後, 人工便をモノジェクターを用い直接肚 門から注入した。次いで，透視台に固定した自作 の便座に座らせ, 右側面からレントゲン透視下に 安静時, 肛門収縮時, 怒責時のレントゲン撮影を 行った。怒責時撮影は人工便が排出されているこ とを確認しながら撮影した。そして，得られたフ イルムから, 会陰下垂の程度については, 恥骨上 縁と尾骨下縁を結ぶ直線と平行な直腸肛門連結部 を通過する線との間に直角に線を引き，その距離 を測定し, 安静時に $2 \mathrm{~cm}$ 以上, 怒責時に $3 \mathrm{~cm}$ 以上 ある場合を, 会陰下垂pelvic floor descent陽性(会 陰下垂症候群）とした。なお，怒責時に肛門管が 開かない場合を恥骨直腸筋弛緩不全, 肛門管収縮 時と同様またはそれ以上に恥骨直腸筋の収縮を認 める恥骨直腸筋奇異性収縮を恥骨直腸筋症候群と した。なお, rectoceleの大きさは, 怒責時におい て, 肛門管長軸の延長線にrectocele頂点から垂線 を引き交差する所までの距離とした（Fig. 1)。

統計学的解析には, Chi-square testを用い, $\mathrm{p}<$ 0.05を持って有意とした。

\section{成 績}

Defecography所見から rectoceleは, 男性対象 の11.3\%（8/71）に認められた。

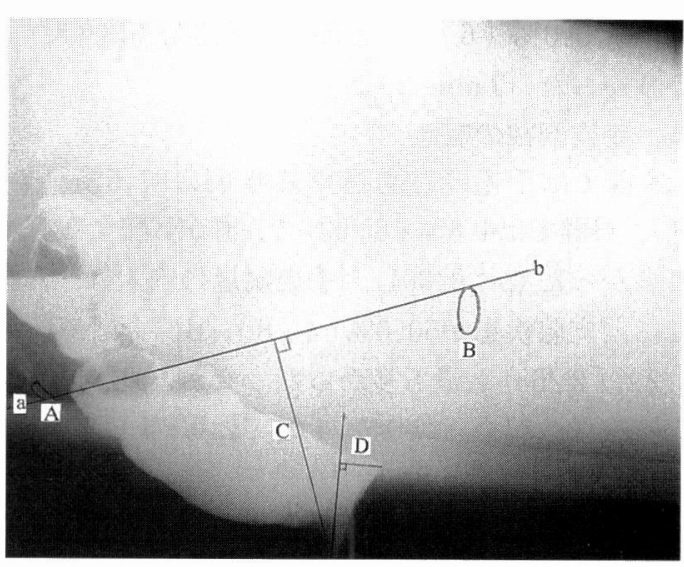

Fig. 2 Defaecating proctogram

Defecography showed a rectocele and perineal descent (a 65 year old male with prostatectomy for prostatic carcinoma).

A : Coccyx, B : Pubis, C : Perineal descent $(7 \mathrm{~cm})$, $D$ : Length (size) of rectocele $(1.5 \mathrm{~cm})$ $a b$ : The pubococcygeal line

Table 1 Chief complaints

\begin{tabular}{lcll}
\hline \multicolumn{1}{c}{ Symptoms } & $\begin{array}{l}\text { Group A } \\
\text { Rectocele }(+)\end{array}$ & $\begin{array}{l}\text { Group B } \\
\text { Rectocele (-) }\end{array}$ & p value \\
\hline $\begin{array}{l}\text { A sense of incomplete } \\
\text { emptying of the rectum }\end{array}$ & $100 \%(8 / 8)$ & $36.5 \%(23 / 63)$ & \\
$\begin{array}{l}\text { Constipation } \\
\begin{array}{l}\text { Perineal pain with } \\
\text { defecation }\end{array}\end{array}$ & $0 \%(0 / 8)$ & $31.7 \%(20 / 63)$ & \\
$\begin{array}{l}\text { Difficulty in bowel } \\
\text { emptying }\end{array}$ & $0 \%(0 / 8)$ & $11.1 \%(7 / 63)$ & \\
$\begin{array}{l}\text { Discomfert in the } \\
\text { perineal area } \\
\text { Others }\end{array}$ & $0 \%(0 / 8)$ & $6.5 \%(6 / 63)$ & \\
\hline \multicolumn{1}{c}{ Total } & $0 \%(0 / 8)$ & $4.8 \%(3 / 63)$ & \\
\hline
\end{tabular}

怒責時レントゲン写真の典型例を提示する。症 例は65歳, 男性, 前立腺癌で前立腺摘出手術を約 3 年前に受けており, rectoceleと会除下垂を認め る (Fig. 2)。

\section{1. 主訴}

残便感はA群では $100 \%$ （8/8), B群では36.5 \%（23/63）に認められた。残便感はA群がB群よ り有意に多く認めた $(\mathrm{p}<0.05) \quad($ Table 1$)$ 。

\section{2 . 排便習慣}

排便回数は, A群では 1 回 /日が50.0\% (4/ $8)$, B群では 2 回/週が41.3\% (26/63) を占めた (Table 2)。A群はB 群より有意に排便回数は多 かった $(\mathrm{p}<0.05)$ 。排便時怒責を認めるものは, 
A群が75.0\% (6/8) とB群の68.3\% (43/63)よ り多かった (Table 2)。

\section{3 . 手術既往の有無}

A群では手術既往を有する症例は87.5\%（7/ 8 ), B群では4.8\% ( $3 / 63)$ でA群がB群より有意 に多かった $(\mathrm{p}<0.001)$ 。手術疾患の内訳は，A群 では前立腺疾患が50.0\%(4/8)，B群では痔核が $3.2 \%(2 / 63)$ と最も多かった。なお，B群では前 立腺疾患は認められなかった（Table 3)。

\section{4. defecography所見}

1 ) 怒責時defecography所見

Table 2 Bowel habits

\begin{tabular}{|c|c|c|c|}
\hline & $\begin{array}{l}\text { Group A } \\
\text { Rectocele (t) }\end{array}$ & $\begin{array}{l}\text { Group B } \\
\text { Rectocele (-) }\end{array}$ & $P$ value \\
\hline $\begin{array}{l}\text { Once per day } \\
\text { Twice per week } \\
\text { Once per weak } \\
\text { Once per two weaks } \\
\text { More than twice per day }\end{array}$ & $\begin{array}{r}50.0 \%(4 / 8) \\
12.5 \%(1 / 8) \\
0 \%(0 / 8) \\
0 \%(0 / 8) \\
37.5 \%(3 / 8)\end{array}$ & $\begin{array}{l}15.9 \%(10 / 63) \\
41.3 \%(26 / 63) \\
15.9 \%(10 / 63) \\
26.9 \%(17 / 63) \\
26.9 \%(17 / 63)\end{array}$ & $\mathrm{p}<0.05$ \\
\hline $\begin{array}{l}\text { Defecation with straining } \\
\text { Defecation without straining }\end{array}$ & $\begin{array}{l}75.0 \%(6 / 8) \\
25.0 \%(2 / 8)\end{array}$ & $\begin{array}{l}68.3 \%(43 / 63) \\
31.7 \%(20 / 63)\end{array}$ & ns \\
\hline Total & 8 & 63 & \\
\hline
\end{tabular}

Table 3 Past history of the surgical treatments

\begin{tabular}{lccc}
\hline & $\begin{array}{l}\text { Group A } \\
\text { Rectocele (+) }\end{array}$ & $\begin{array}{l}\text { Group B } \\
\text { Rectocele (-) }\end{array}$ & p value \\
\hline Surgical treatment (+) & $87.5 \%(7 / 8)$ & $4.8 \%(3 / 63)$ & $\mathrm{p}<0.0001$ \\
Prostatectomy & $50.0 \%(4 / 8)$ & $0 \%(0 / 63)$ & \\
low anterior resection & $12.5 \%(1 / 8)$ & $0 \%(0 / 63)$ & \\
Hemorrhoidectomy & $25.0 \%(2 / 8)$ & $3.2 \%(2 / 63)$ & \\
Sigmoidectomy & $0 \%(0 / 8)$ & $1.6 \%(1 / 63)$ & \\
\hline \multicolumn{1}{c}{ Total } & 8 & 63 & \\
\hline
\end{tabular}

A群では全例が直腸壁異常 (rectocele, 直腸重 責) と骨盤底筋群異常（会陰下垂, 恥骨直腸筋症 候群)を伴っていたが，B群では直腸壁異常 (直腸 重責，粘膜脱症候群）は11.1\%（7/63），骨盤底 筋群異常 (逆説性恥骨直腸収縮, 恥骨直腸筋非弛 緩)は38.1\% (26/63)，両者の異常は23.8\%（15/ 63）であり，異常が全く認められない症例も 23.8 \% (15/63) に認められた。直腸壁異常と骨盤底筋 群異常の両者を認めた症例は, $\mathrm{A}$ 群がB群より有 意に多かった $(\mathrm{p}<0.001)$ (Table 4$)$ 。

2 ) rectoceleの大きさ

0.5 2.0 cmであり, 平均 $1.28 \mathrm{~cm}$ であった。

\section{考察}

直腸壁の形態学的異常である rectocele ${ }^{1) \sim 5)}$ は, 排便時怒責による直腸内圧上昇に伴って，女性で は直腸壁の胵側が, 男性では膀胱側が, その大き さに関係なく袋状に拡張して突き出る疾患である ことから, 直腸瘤と呼ばれることもある。しかし, 一般にはrectoceleとして呼ぶことが多い。性別は 女性に多く，男性は稀であり $0 \sim 9.3 \%$ と報告(4)67) されている。年歯分布は，女性では20歳代から 80 歳代まで幅広くみられ，40～50歳代にピークを認

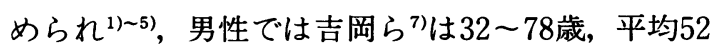
歳であったと報告している。われわれの症例も 15 73歳, 平均48.6歳と吉岡ら ${ }^{7)}$ 同様, 女性と類 似した年齢分布を示した。なお， defecographyに

Table 4 Findings of the defecogram

\begin{tabular}{|c|c|c|c|}
\hline & $\begin{array}{l}\text { Group A } \\
\text { Rectocele (+) }\end{array}$ & $\begin{array}{l}\text { Group B } \\
\text { Rectocele (-) }\end{array}$ & $p$ value \\
\hline \multicolumn{4}{|l|}{ 1) Abnormalities of the rectal wall } \\
\hline $\begin{array}{l}\text { Rectal intussusception } \\
\text { Mucosal prolapse syndrome } \\
\text { Rectocele }\end{array}$ & & $\begin{array}{l}7.9 \%(5 / 63) \\
3.2 \%(2 / 63)\end{array}$ & \\
\hline \multicolumn{4}{|l|}{ 2) Abnormalities of the levator muscles } \\
\hline $\begin{array}{l}\text { Puborectalis syndrome } \\
\text { Paradoxical contraction of puborectalis muscle } \\
\text { Non-relaxing puborectalis muscle (NP) } \\
\text { Perineal descending syndrome (PD) }\end{array}$ & & $\begin{array}{c}14.3 \%(9 / 63) \\
7.9 \%(5 / 63) \\
19.0 \%(12 / 63)\end{array}$ & \\
\hline \multicolumn{4}{|l|}{ 3) 1) + 2) } \\
\hline $\begin{array}{l}\text { Rectal intussusception + PD } \\
\text { Rectal intussusception + NP } \\
\text { Rectocele + Rectal intussusception + PD } \\
\text { Rectocele + PD } \\
\text { Rectocele + NP }\end{array}$ & $\begin{array}{l}37.5 \%(3 / 8) \\
37.5 \%(3 / 8) \\
25.0 \%(2 / 8)\end{array}$ & $\begin{array}{r}14.3 \%(9 / 63) \\
9.5 \%(6 / 63)\end{array}$ & $\mathrm{p}<0.001$ \\
\hline 4) Normal defecogram & & $23.8 \%(15 / 63)$ & \\
\hline Total & 8 & 63 & \\
\hline
\end{tabular}


よる発見頻度は，11.3\%とこれまでの報告例より 多かった。

病因については，これまで女性を中心に研究さ れ, 加齢, 排便障害（慢性便秘や排便困難など） や不良な排便習慣による怒責, 出産, 閉経後の工 ストロゲン分泌低下などから生じる骨盤底・会陰 部組織の脆弱化から形成される48)ことが考之ら れている。また, Delancey ${ }^{9}$ は, 死体解剖所見から rectoceleは泌尿生殖隔膜や骨盤底筋群の脆弱が 原因で生じるとした。男性のrectoceleの病因につ いてCavalloら6)は, 前立腺摘出術を受けている症 例が多いことから，前立腺摘出により生じた凹み に直晹壁前方が突出してrectoceleが形成される とした。われわれの症例は, rectoceleを伴う症例 は，伴わない症例より明らかに前立腺摘出術や直 腸肛門手術などを受けていた。したがって，手術 操作による骨盤底筋群や直腸周囲の支持組織の脆 弱化や，前立腺摘出により生じた凹みが原因で生 じた可能性が示唆された。

症状については，女性では残便感，便秘，排便 困難などを訴えることが多いことが知られてい

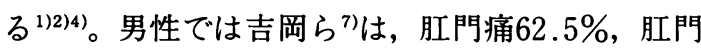
出血 $37.5 \%$, 残便感 $25 \%$ と報告している。われわ れの症例は全例が残便感を訴之たが，これは吉岡 $ら^{77}$ が直腸肛門症状を主訴とした症例を対象とし ているのに対して，著者らは排便困難を主訴とし た症例を対象にしたことによる相違と考えてい る。

診断については, defecography検查で怒責時に 直腸前壁が前方に袋状に突き出ていることで診断 される(12)4。女性では付随的所見として, 安静時と 怒責時の会陰下垂程度は健常人より高度であるが 多く, 症状の有無から rectoceleの大きさの研究が 行われ，2 cm以下では無症状例10111)，2３cm以 上では有症状例が多い ${ }^{1112)}$ とする報告が多い。そ して， $2 \mathrm{~cm}$ 以上の大きいrectoceleは排便後も便 がrectocele内に残り残便感をもたらす ${ }^{12}$ という。 われわれの症例の大きさは $1 \mathrm{~cm}$ 以下が多く，2 $\mathrm{cm}$ 以上は 1 例のみでrectocele内にバリウムの貯 留は認められなかった。なお，会陰下垂を多く伴 い，直腸重責や恥骨直腸筋症候群も認められた。 したがって, 残便感の原因はrectoceleのみによる
とは考えにくく，随伴する会陰下垂や直腸重責な どにより残便感が生じる可能性もあると考えてい る。

治療については, Murthyら ${ }^{8 /}$ は女性のrectocele と同様 ${ }^{13} に$ にdefecography所見において, 大きさ 2 cm以上の症例でrectocele内にバリウムが貯留す る症例に外科治療（経肛門的あるいは経会陰的な rectocele縫縮術）を行っている。その他は保存的 治療が行われ，薬物療法(緩下郕, 整腸剂), 食事 療法(高緘維食), 排便習慣改善指導などで, 便通 を整えることを目的としている4。 。れわれの症 例は $2 \mathrm{~cm}$ 以下と小さく, バリウムの貯留も認めな いため，保存的治療で経過観察をしているが， 2 例に症状の改善が認められた（1例はbiofeedback療法を併用)。

以上，男性のrectoceleについて臨床的検討を行 ったが，その原因には手術による骨盤底筋群や直 腸周囲支持組織の脆弱化が考之られた。しかし, defecography所見では大きさは小さく，付随的所 見として直腸壁と骨盤底筋群の異常を認めたこと から, 残便感はrectoceleにより生じるとは考之に くかった。今後さらに症例を重ね，直腸肛門生理 機能検查を用い病態生理学的解明が必要と思われ る。

\section{結語}

これまで男性には稀とされていた rectoceleは, 排便障害を主訴にする男性患者にdefecography を用いることで $11.3 \%$ に認められた。したがって， 男性においても残便感などの排便障害を主訴とす る患者に是非応用されるべき検査法である。

\section{参考文献}

1) Bartolo D CC, Read NW, Jarratt JA, et al: Differences in anal sphincter function and clinical presentation in patients with pelvic floor descent. Gastroenterology $83: 68-75,1983$

2）朴 哲在, 季 基周, 隅越幸男 : 排便障害診断 ; Defecography. 日本大腸肛門病会誌 $43 ： 606$ 612, 1990

3）天野信一：直腸瘤の診断一直腸指診から一. Therapeutic Res 12：115-118，1991 
4）富田凉一：大腸の機能性疾患. Med Postgrad $35: 64-74,1997$

5）富田凉一, 五十嵐誠悟, 萩原紀嗣他：直腸内圧か らみたRectoceleの病態生理学的検討. 日本大腸 肛門病会誌51：101-108, 1998

6) Cavallo G, Salazano A, Grassi R, et al : Clinical, defecographic, and CT study of singular cases. Dis Colon Rectum 34 : 964-966, 1991

7）吉岡和彦, 今田世紀, 中野雅貴他：男性における rectoceleの生理学的および解剖学的検討. 日本大 腸肛門病会誌 $52 ： 43-47,1999$

8) Murthy VK, Orkin BA, Smith LE, et al : Excellent outcome using selective criteria for rectocele repair. Dis Colon Rectum 39 :374378, 1999

9) Delancey JO : Structural anatomy of the posterior pelvic compartment as it relates to rectocele. Am J Obstet Gynecol 180 : 815-823, 1999

10) Mellgren A, Johansson C, Dolk A, et al : Enterocele demonstrated by defaecography is associated with other prlvic floor disorders. Int $\mathrm{J}$ Colorect Dis $9: 121-124,1994$

11) Halligan $\mathrm{S}$, Bartram $\mathrm{CI}$ : Is digitation associated with proctographic abnormality? Int J Colorect Dis $11: 167-171,1996$

12) Siproudhis L, Ropert A, Lucas J, et al: Defecatory disorders, anorectal and pelvic floor dysfunction : a polygamy? Int J Colorect Dis $7: 102-107,1992$

13）富田凉一, 池田太郎, 朴 英智他: Soilingを伴っ た rectoceleに对する経会陰的縫縮術にanterior levatorplastyを付加した術式. 手術55：851-855, 2001 